\title{
EFEKTIFITAS PENGEMBANGAN PERANGKAT PEMBELAJARAN IPA BERBASIS MODEL PROBLEM BASED INSTRUCTION TERINTEGRASI PENDIDIKAN KARAKTER UNTUK SISWA SEKOLAH DASAR
}

\author{
Estuhono \\ Fakultas Keguruan dan Ilmu Pendidikan, Universitas Dharmas Indonesia \\ e-mail:estuhono023@gmail.com.
}

\begin{abstract}
This research was conducted based on the development of learning tools that encourage students' creativity and skills in solving problems and motivating students to more active in the learning process. Besides that, it needed to develop students' character values in the learning process. The development of learning tools based on integrated character education through a problem-based learning model can give solutions to this problem. The purpose of this research is to development of science learning tools for force materials based on integrated character education problem-based learning (PBI) model. This research is R \& D and uses the plomp model. The Plomp model consists of the preliminary, prototyping phase, and assessment phase. The initial research phase needs analysis and contexts, literature review, and development design theory. The result of practical test based on teacher demonstrated that the score was $92.5 \%$ with the actual type. The result of students by using science learning tools shown that the cognitive category was $66 \%$, assessment of affective nature was $72 \%$, and the assessment of psychomotor was $95 \%$. Based on the three types above, the average of students' outcomes was $77.6 \%$ with the current category.
\end{abstract}

Keywords: Development; Problem Based Instruction; Students Character.

\begin{abstract}
Abstrak
Penelitian ini dilatar belakangi pentingnya pengembangan perangkat pembelajaran yang mendorong kreatifitas dan keterampilan siswa dalam memecahkan masalah serta memotivasi siswa untuk berperan aktif dalam pembelajaran. Salah satunya dengan mengintegrasikan nilai-nilai karakter ke dalam pembelajaran, yaitu pada pembelajaran IPA di SD. Tujuan penelitian ini adalah untuk mengembangkan perangkat pembelajaran IPA berbasis model PBI terintegrasi pendidikan karakter. Jenis penelitian adalah penelitian pengembangan (R\&D) dengan menggunakan model pengembangan Plomp yang terdiri dari tahap penelitian pendahuluan, tahap prototipe dan tahap penilaian. Tahap penelitian pendahuluan dilakukan analisis kebutuhan dan konteks, literature review, dan pengembangan kerangka teori. Hasil penilaian keterlaksanaan perangkat pembelajaran IPA berbasis model PBI terintegrasi pendidikan karakter yang dinilai oleh guru kelas mempunyai skor $92,5 \%$ dengan kategori sangat praktis. Hasil belajar siswa setelah menggunakan perangkat pembelajaran IPA berbasis model PBI terintegrasi pendidikan karakter yang terdiri dari penilaian aspek pengetahuan dengan persentase sebesar $66 \%$, penilaian aspek afektif (karakter) dengan persentase $72 \%$, serta penilaian aspek psikmotor dengan persentase $95 \%$. Sehingga dari ketiga ranah hasil belajar tersebut didapatkan rata-rata $77,6 \%$ dengan kategori efektif.
\end{abstract}

Kata Kunci: Pengembangan; Perangkat; PBI; Karakter.

\section{PENDAHULUAN}

Pendidikan karakter merupakan suatu pendidikan yang mengembangkan nilai-nilai karakter yang harus dimiliki oleh siswa agar nantinya siswa menjadi seseorang yang 
berperilaku baik. Sehubungan dengan ini, (Kurniawan, 2013) menyebutkan bahwa "Pendidikan karakter adalah suatu proses penanaman nilai-nilai karakter kepada peserta didik agar menjadi manusia seutuhnya yang berkarakter dalam dimensi hati, pikir, raga, serta rasa dan karsa". Penjelasan ini menegaskan bahwa pendidikan karakter merupakan suatu pendidikan yang dilaksanakan untuk mengembangkan nilai-nilai perilaku, budaya dan karakter bangsa pada diri siswa untuk diinternalisasikan oleh siswa dan menerapkannya dalam kehidupan sehari-hari.

Nilai-nilai pendidikan karakter diperoleh siswa dari hasil pengintegrasian nilai tersebut di dalam proses pembelajaran yang dilaksanakan untuk semua mata pelajaran terutama di dalam mata pelajaran Ilmu Pengetahuan Alam (IPA). Mata pelajaran IPA sebagai salah satu mata pelajaran yang diajarkan di sekolah dasar tentunya juga dapat dijadikan sebagai sarana pengimplementasian nilai-nilai pendidikan karakter. IPA merupakan mata pelajaran sains yang menjelaskan berbagai gejala fisik fenomena yang terjadi di alam, baik secara teoritis maupun matematis (Estuhono, Festiyed \& Bentri, 2020). Dengan adanya hal tersebut dapat mengindikasikan bahwa terdapat ruang-ruang yang dapat dijadikan sebagai sarana dalam mengembangkan nilai-nilai pendidikan karakter kepada siswa dalam pembelajaran IPA.

Namun pada kenyataannya, masih banyak sekolah-sekolah yang belum mengintegrasikan nilai-nilai karakter dalam proses pembelajaran terutama pada pembelajaran IPA. Berdasarkan observasi yang dilakukan di SDN 10 Sitiung diketahui bahwa nilai-nilai karakter belum diintegrasikan pada saat proses pembelajaran di kelas. Dampak belum terintegrasinya pendidikan karakter di sekolah akan mengurangi motivasi siswa dalam meraih prestasi akademik dan juga akan berpengaruh pada perilaku negatif siswa yang dapat menghambat keberhasilan akademik.

Salah satu upaya strategis yang dapat dilakukan untuk mengatasi permasalah di atas adalah melalui pengembangan suatu perangkat pembelajaran IPA yang mengintegrasikan nilai-nilai pendidikan karakter yang sesuai dengan karakteristik siswa. Perangkat pembelajaran IPA yang akan dikembangkan terdiri dari Silabus, RPP, Modul dan Penilaian menggunakan model pembelajaran Probelm Based Instruction (PBI). Nilai-nilai karakter yang akan dimunculkan dalam pembelajaran dalam materi pembelajaran IPA ialah religius, jujur, displin, rasa ingin tahu, tanggung jawab, komunikatif, kreatif, toleransi. Model PBI merupakan model pembelajaran yang berlandaskan paham konstruktivistik yang mengakomodasi keterlibatan siswa dalam belajar dan pemecahan masalah. Melalui penerapan model PBI ke dalam perangkat pembelajaran yang dikembangkan memungkinkan siswa belajar secara aktif, menyenangkan sehingga diharapkan mampu menumbuhkan karakter positif dalam diri siswa

\section{METODE}

Metode penelitian ini menggunakan model pengembangan Plomp (2013) yang terdapat 3 tahap yaitu tahap penelitian pendahuluan (Preminery Research), tahap prototype (Prototyping Phase), dan tahap penilaian (Assesment Phase).

\section{HASIL DAN PEMBAHASAN \\ HASIL}

\section{1) Hasil Penilaian Aspek Pengetahuan}

Berdasarkan Tabel 1. dapat dilihat bahwa dari keseluruhan siswa kelas IV SD Negeri 10 Sitiung yang berjumlah 15 siswa, 10 siswa mendapatkan nilai di atas KKM yaitu 75 dan 5 siswa mendapatkan nilai di bawah KKM. Nilai keseluruhan siswa didapatkan 76,56 dan persentase ketuntasan didapatkan $66 \%$ dengan kategori efektif. Sehingga perangkat 
pembelajaran IPA berbasis model problem based instruction terintegrasi pendidikan karakter dikatakan efektif dalam meningkatkan hasil belajar ranah pengetahuan siswa

Tabel 1. Hasil Penilaian Aspek Pengetahuan Siswa

\begin{tabular}{ccccc}
\hline $\begin{array}{c}\text { Nilai rata- } \\
\text { rata }\end{array}$ & $\begin{array}{c}\text { Siswa yang } \\
\text { tuntas }\end{array}$ & $\begin{array}{c}\text { Siswa yang } \\
\text { tidak tuntas }\end{array}$ & $\begin{array}{c}\text { Persentase } \\
\text { ketuntasan } \mathbf{( \% )}\end{array}$ & Kategori \\
\hline 76,56 & 10 & 5 & 66 & Efektif \\
\hline
\end{tabular}

\section{2) Penilaian Aspek Karakter Siswa}

Hasil penilaian karakter siswa diperoleh dari hasil pengamatan karakter siswa selama proses pembelajaran. Data yang diperoleh dari lembar observasi yang diisi oleh observer untuk mengamati berbagai keterampilan siswa selama proses pembelajaran. Hasil obsevasi terhadap karakter siswa dapat dilihat secara ringkas pada Tabel 2.

Tabel 2. Hasil Penilaian Karakter Siswa

\begin{tabular}{lcl}
\hline \multicolumn{1}{c}{ Pertemuan } & Nilai rata-rata kelas (\%) & \multicolumn{1}{c}{ Kategori } \\
\hline Pertama & 49 & Mulai Terlihat \\
Kedua & 66 & Mulai Berkembang \\
Ketiga & 81 & Mulai Berkembang \\
Keempat & 93 & Menjadi Kebiasaan \\
Nilai rata-rata Kelas & 72 & Mulai Berkembang \\
\hline
\end{tabular}

(Sumber: Kelas IV SDN 10 Sitiung)

Tabel 2. menunjukkan bahwa karakter siswa berada pada kategori mulai berkembang dengan nilai rata-rata kelas sebesar $72 \%$. Pertemuan pertama hingga pertemuan keempat menunjukkan bahwa karakter positif siswa mengalami peningkatan. Interprestasi penilaian prilaku karakter siswa diperoleh dari hasil pengamatan terhadap siswa selama proses pembelajaran. Data diperoleh dari lembaran observasi karakter siswa selama proses pembelajaran. Observasi ini dilakukan untuk mengetahui kriteria perilaku berkarakter yang dimiliki siswa apakah belum terlihat (BT), mulai terlihat (MT), mulai berkembang (MB) atau menjadi kebiasaan (MK).

a. Hasil Penilaian Karakter Pertemuan Pertama

Hasil observasi terhadap karakter siswa pada pertemuan pertama dapat dilihat pada lampiran VIII dan secara ringkas dapat dilihat pada Tabel 3.

Tabel 3. Hasil Penilaian Karakter Siswa Pertemuan Pertama

\begin{tabular}{clcl}
\hline No. & Aspek Karakter & Pesentase (\%) & \multicolumn{1}{c}{ Kategori } \\
\hline 1. & Religius & 55 & Mulai Berkembang \\
2. & Disiplin & 48 & Mulai Terlihat \\
3. & Kreatif & 46 & Mulai Terlihat \\
4. & Jujur & 49 & Mulai Terlihat \\
5. & Tanggung Jawab & 49 & Mulai Terlihat \\
6. & Toleransi & 47 & Mulai Terlihat \\
7. & Rasa Ingin Tahu & 51 & Mulai Berkembang \\
\hline & Rata-rata & 49 & Mulai Terlihat \\
\hline
\end{tabular}

Tabel 3. menunjukkan bahwa perilaku karakter siswa berada pada kategori melai terlihat dengan persentase rata-rata sebesar $49 \%$. Grafik peningkatan perilaku berkarakter siswa pada pertemuan pertama dapat dilihat pada Gambar 1. 


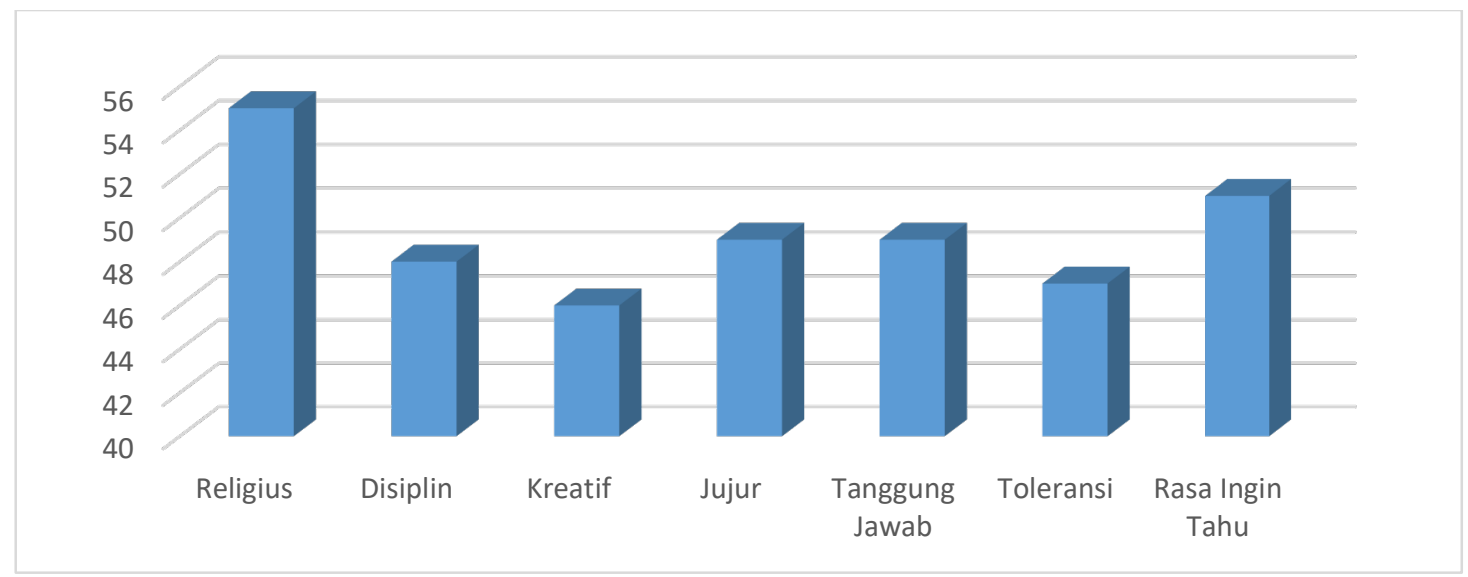

Gambar 1. Grafik Peningkatan Perilaku Berkarakter Siswa Pertemuan Pertama

Berdasarkan Gambar 1. dapat diketahui bahwa karakter pada diri siswa secara umum sudah mulai terlihat dan mulai berkembang. Karakter yang paling menonjol pada pertemuan pertama adalah religius. Penggunaan perangkat pembelajaran yaitu salah satunya adalah modul yang memang membiasakan siswa untuk bersikap religius.

\section{b. Hasil Penilaian Karakter Pertemuan Kedua} Tabel 4.

Hasil observasi karakter siswa pada pertemuan kedua secara ringkas dapat dilihat pada

Tabel 4. Hasil Penilaian Karakter Siswa Pertemuan Kedua

\begin{tabular}{llll}
\hline No. & \multicolumn{1}{c}{ Aspek Karakter } & Pesentase (\%) & \multicolumn{1}{c}{ Kategori } \\
\hline 1. & Religius & 75 & Mulai Berkembang \\
2. & Disiplin & 61 & Mulai Berkembang \\
3. & Jujur & 68 & Mulai Berkembang \\
4. & Tanggung Jawab & 60 & Mulai Berkembang \\
5. & Toleransi & 66 & Mulai Berkembang \\
6. & Rasa Ingin Tahu & 63 & Mulai Berkembang \\
\hline & Rata-rata & 66 & Mulai Berkembang \\
\hline
\end{tabular}

(Sumber: Kelas IV SDN 10 Sitiung)

Tabel 4. menunjukkan bahwa perilaku karakter siswa berada pada kategori mulai terlihat dengan persentase rata-rata sebesar $66 \%$. Grafik peningkatan perilaku berkarakter siswa pada pertemuan pertama dapat dilihat pada Gambar 2.

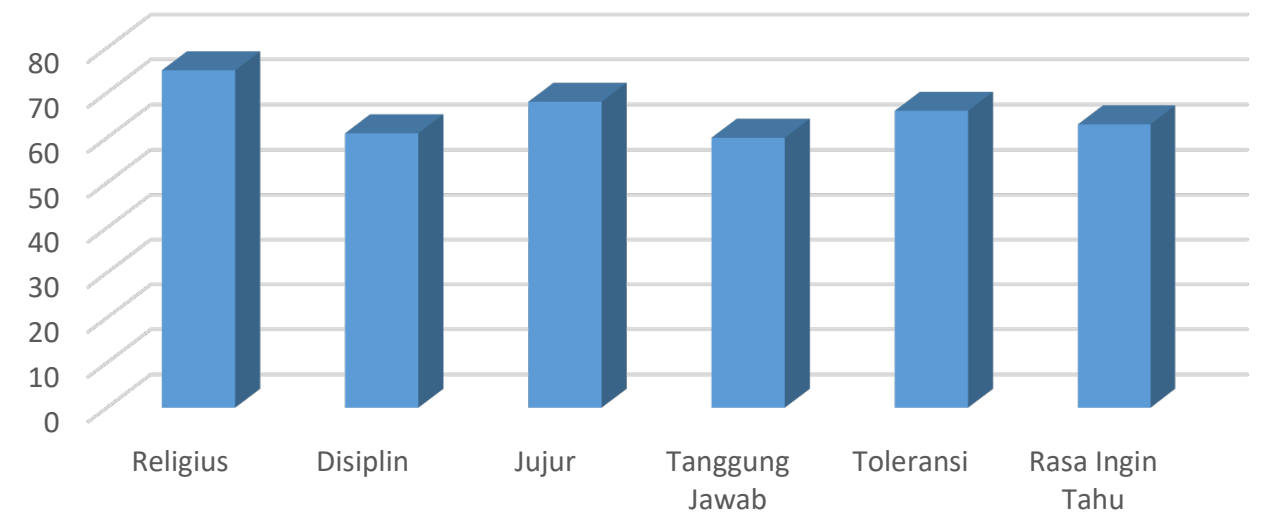

Gambar 2. Grafik Peningkatan Perilaku Berkarakter Siswa Pertemuan Kedua 
Berdasarkan Gambar 2. dapat diketahui bahwa karakter pada diri siswa secara umum sudah mulai berkembang. Karakter yang paling menonjol pada pertemuan kedua adalah religius dan jujur. Penggunaan perangkat pembelajaran yang dapat membuat siswa menjadi mandiri dengan disediakannya soal-soal latihan yang mewajibkan siswa untuk mengerjakan secara jujur.

c. Hasil Penilaian Karakter Pertemuan Ketiga

Hasil observasi terhadap karakter siswa pada pertemuan ketiga berdasarkan beberapa aspek dapat dilihat pada Tabel 5.

Tabel 5. Hasil Penilaian Karakter Siswa Pertemuan Ketiga

\begin{tabular}{|c|c|c|c|}
\hline No. & Aspek Karakter & Persentase (\%) & Kategori \\
\hline 1. & Religius & 82 & Menjadi Kebiasaan \\
\hline 2. & Disiplin & 80 & Menjadi Kebiasaan \\
\hline 3. & Jujur & 81 & Menjadi Kebiasaan \\
\hline 4. & Tanggung Jawab & 81 & Menjadi Kebiasaan \\
\hline 5. & Toleransi & 80 & Menjadi Kebiasaan \\
\hline \multirow[t]{2}{*}{6.} & Rasa Ingin Tahu & 82 & Menjadi Kebiasaan \\
\hline & Rata-rata & 81 & Menjadi Kebiasaan \\
\hline
\end{tabular}

(Sumber: Kelas IV SDN 10 Sitiung)

Pada Tabel 5. dapat dilihat bahwa perilaku karakter siswa pada pertemuan ketiga berada pada kategori menjadi kebiasaan dengan persentase sebesar $81 \%$. Peningkatan perilaku karakter siswa dapat dilihat pada grafik yang di ditunjukkan Gambar 3.

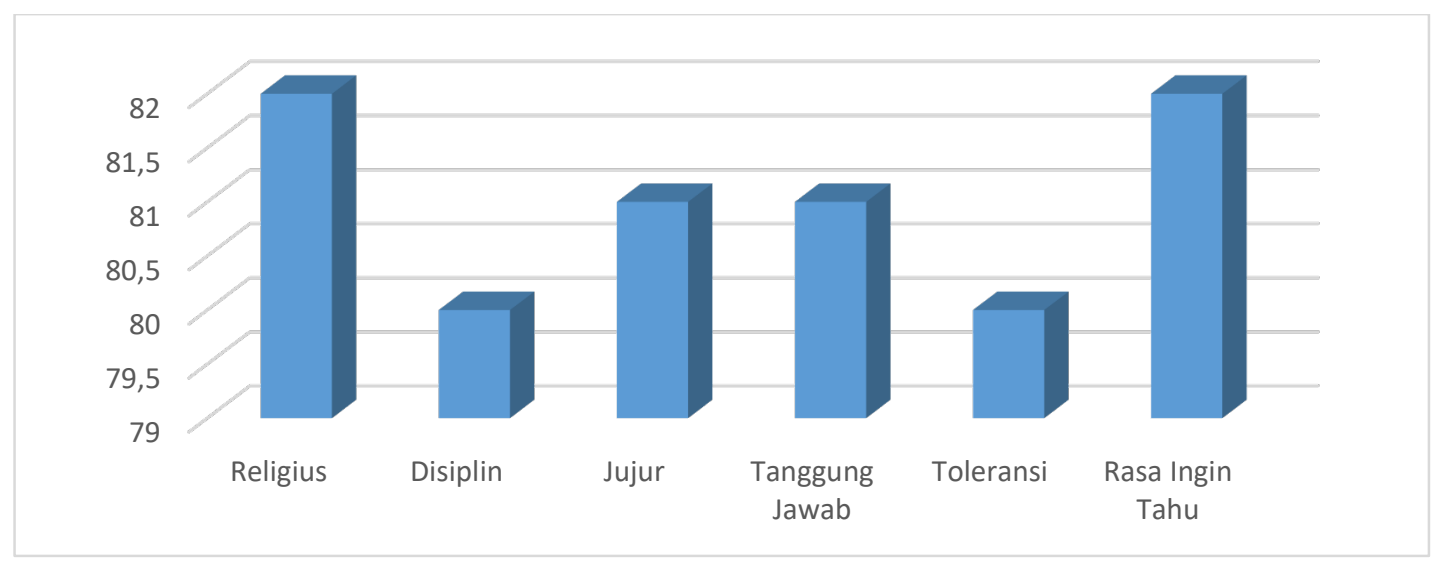

Gambar 3. Grafik Peningkatan Perilaku Berkarakter Siswa Pertemuan Ketiga

Berdasarkan Gambar 3. dapat dilihat bahwa perilaku siswa mengalami peningkatan dari pertemuan sebelumnya. Tabel menunjukkan bahwa karakter pada diri siswa secara umum sudah menjadi kebiasan. Karakter yang paling menonjol pada pertemuan ketiga adalah religius dan rasa ingin tahu. Perangkat pembelajaran yang memungkinkan siswa untuk lebih mandiri dalam hal apapun, selain itu juga disediakan soal-soal yang harus dikerjakan.

d. Hasil Penilaian Karakter Pertemuan Keempat

Hasil observasi penilaian karakter siswa pada pertemuan keempat pada kategori menjadi kebiasaan dengan persentase rata-rata 93\%.dapat dilihat pada Tabel 6 . Berdasarkan pertemuan pertama hingga pertemuan keempat dapat diketahui bahwa karakter siswa mengalami peningkatan dan sudah menjadi kebiasaan. Secara keseluruhan perilaku karakter siswa pada setiap pertemuan mengalami peningkatan. Perangkat pembelajaran IPA yang terintegrasi pendidikan karakter menjadi baik dan menjadi terbiasa dalam proses pembelajaran. Sehingga dapat dikatakan bahwa perangkat pembelajaran IPA yang dikembangkan dapat menumbuhkembangkan karakter siswa dengan baik. 
Tabel 6. Hasil Penilaian Karakter Siswa pada Pertemuan Keempat

\begin{tabular}{clcl}
\hline No & Aspek Karakter & Persentase (\%) & Kategori \\
\hline 1. & Religius & 95 & Menjadi Kebiasaan \\
2. & Disiplin & 90 & Menjadi Kebiasaan \\
3. & Kreatif & 90 & Menjadi Kebiasaan \\
4. & Jujur & 95 & Menjadi Kebiasaan \\
5. & Tanggung Jawab & 93 & Menjadi Kebiasaan \\
6. & Toleransi & 92 & Menjadi Kebiasaan \\
7. & Komunikatif & 93 & Menjadi Kebiasaan \\
8. & Rasa Ingin Tahu & 94 & Menjadi Kebiasaan \\
\hline & Rata-rata & 93 & Menjadi Kebiasaan \\
\hline
\end{tabular}

Pada pertemuan keempat persentase karakter siswa sudah mengalami peningkatan yang bagus dan rata-rata keseluruhan karakter sudah menonjol. Hal ini dikarenakan penggunaan perangkat pembelajaran yang memungkin siswa untuk menjadi terbiasa dalam menerapkan perilaku karakter positif dalam kegiatan pembelajaran.

\section{3) Hasil Penilaian Aspek Keterampilan}

Hasil belajar pada aspek keterampilan diambil berdasarkan aktivitas dan kegiatan siswa dalam melakukan praktikum. Hasil penilaian aspek keterampilan secara ringkas dapat dilihat pada Tabel 7 .

Tabel 7. Hasil Penilaian Aspek Keterampilan

\begin{tabular}{|c|c|c|c|c|c|}
\hline \multirow[t]{2}{*}{ Aktivitas Siswa } & \multicolumn{4}{|c|}{$\begin{array}{c}\text { Presentase Nilai } \\
\text { Setiap Pertemuan } \\
(\%)\end{array}$} & \multirow[t]{2}{*}{ Kategori } \\
\hline & P1 & P2 & P3 & P4 & \\
\hline Menyiapkan alat-alat eksperimen & 100 & 100 & 100 & 100 & SB \\
\hline Merangkai alat/bahan eksperimen & 100 & 100 & 100 & 100 & SB \\
\hline Partisipasi dalam setiap Langkah-langkah eksperimen & 95 & 100 & 95 & 100 & SB \\
\hline Ketepatan menggunakan alat & 95 & 91 & 93 & 100 & SB \\
\hline Membaca dan mencatat hasil eksperimen & 91 & 91 & 88 & 95 & SB \\
\hline Ketepatan waktu menyiapkan laporan & 95 & 84 & 84 & 91 & SB \\
\hline Rata-rata keseluruhan & & & & & $\mathrm{SB}$ \\
\hline
\end{tabular}

(Sumber: Siswa Kelas IV SDN 10 Sitiung)

Berdasarkan Tabel 7. diketahui bahwa semua indikator yang diobservasi pada kegiatan percobaan telah dilaksankan siswa dengan baik. Nilai keterampilan siswa berkisar antara $76 \%$ sampai 98\% dengan kategori mulai dari baik sampai dengan sangat baik. Nilai keterampilan pada aspek partisipasi dalam setiap langkah-langkah eksperimen mendapat nilai 98\%. Hal ini dikarena siswa sangat tertarik dan sangat antusias untuk melaksanakan percobaan bersama kelompok. Ini berarti pengembangan perangkat pembelajaran IPA berbasis model problem based instruction terintegrasi pendidikan karakter dapat meningkatkan hasil belajar pskomotor siswa. Hasil penilaian pengetahuan, karakter dan keterampilan menunjukkan bahwa perangkat pembelajaran IPA berbasis model problem based instruction terintegrasi pendidikan karakter berada dalam kategori efektif dan layak digunakan dalam kegiatan pembelajaran.

Efektivitas perangkat pembelajaran IPA berbasis model Problem Based Instruction terintegrasi pendidikan karakter dilihat berdasarkan pencapaian penilaian dari hasil tiga aspek penilaian yaitu: hasil penilaian pengetahuan, karakter dan hasil penilaian keterampilan. Proses 
pembelajaran efektif apabila siswa aktif dilibatkan dalam proses pemecahan masalah. Hasil pembelajaran tidak hanya sekedar meningkatkan pengetahuan dari segi pengetahuan saja akan tetapi juga meningkatkan perilaku karakter positif dan keterampilan siswa. Dengan demikian dalam pembelajaran perlu diperhatikan perilaku karakter dan keterampilan siswa selama mengikuti eksperimen dalam proses pembelajaran.

Pada pengembangan perangkat pembelajaran IPA ini peneliti menentukan efektivitas perangkat pembelajaran dengan melihat tiga aspek penilaian sebagaimana yang dijelaskan Tabel 8.

Tabel 8. Efektivitas Perangkat Pembelajaran IPA

\begin{tabular}{cc}
\hline Penilaian & Persentase Pencapaian (\%) \\
\hline Pengetahuan & 66 \\
Karakter/ afektif & 72 \\
Keterampilan & 95 \\
\hline Rata-rata & $\mathbf{7 7 , 6}$ \\
\hline & (Sumber: Kelas IV SDN 10 Sitiung)
\end{tabular}

Tabel di atas menunjukkan bahwa nilai rata-rata efektivitas perangkat pembelajaran IPA mencapai 77,6\%. Sesuai dengan kategori efektivitas yang dimodifikasi Riduwan (2015) termasuk ke dalam kategori efektif. Hal ini sesuai dengan yang dinyatakan oleh Akker (1999) bahwa keefektifan mengacu pada tingkat pengalaman dan hasil sesuai dengan tujuan yang dimaksud. Berdasarkan nilai rata-rata efektivitas perangkat pembelajaran IPA yaitu sebesar 77,6 maka menunjukkan bahwa perangkat pembelajaran IPA berbasis model problem based instruction terintegrasi pendidikan karakter sangat efektif digunakan dalam proses pembelajaran.

\section{PEMBAHASAN}

Perangkat pembelajaran IPA berbasis model probem based instruction terintegrasi pendidikan karakter merupakan salah satu perangkat pembelajaran yang bisa dijadikan sebagai rujukan bagi guru dalam membuat perangkat pembelajaran. Perangkat pembelajaran yang dimaksud yaitu silabus, RPP, modul dan penilaian. Perangkat pembelajaran adalah suatu atau beberapa persiapan yang disusun oleh guru baik secara individu maupun kelompok agar pelaksanaan dan evaluasi pembelajaran dapat dilakukan secara sistematis dan memperoleh hasil seperti yang diinginkan (Rawa $d k k$., 2016). Permendiknas Nomor 41 Tahun 2007 tentang Standar Proses menjelaskan bahwa pengembangan perangkat pembelajaran dilakukan untuk lebih menyesuaikan perangkat pembelajaran yang akan digunakan dengan kondisi yang ada (kebutuhan) dalam kegiatan pembelajaran. Perangkat pembelajaran yang dikembangkan disesuaikan dengan tujuan pembelajaran yang akan dicapai mengenai materi IPA serta pengaplikasian dalam kehidupan sehari-hari (Estuhono, 2017). Pembelajaran hendaknya mengupayakan dan mengkondisikan agar dalam diri siswa tumbuh motivasi yang tinggi untuk terus belajar. Oleh karena itu diperlukannya pengembangan perangkat pembelajaran yang disesuaikan tujuan pembelajaran yang dicapai. Salah satunya yaitu dengan pengembangan perangkat pembelajara IPA berbasis model problem based instruction terintegrasi pendidikan karakter.

Perangkat pembelajaran berbasis model PBI terintegrasi pendidikan karakter ini memfokuskan pada pengembangan perangkat pembelajaran IPA yang terintegrasi 8 dari 18 nilai-nilai pendidikan karakter yakni karakter religius, jujur, disiplin, rasa ingin tahu, tanggung jawab, komunikatif, kreatif, toleransi yang dirancang menyesuaikan karakteristik siswa sekolah dasar dengan model pengembangan Plomp. 


\section{KESIMPULAN}

Hasil belajar siswa setelah menggunakan perangkat pembelajaran IPA berbasis model PBI terintegrasi pendidikan karakter dari ranah pengetahuan diperoleh presentase ketuntasan klasikal sebesar 66\% dengan kategori efektif. Pada aspek karakter diperoleh nilai rata-rata dari setiap pertemuan dengan presentase $72 \%$, yang mampu mengembangkan karakter religius, jujur, kreatif, disiplin, komunikatif, toleransi, tanggung jawab, dan rasa ingin tahu pada diri siswa yang mengalami peningkatan pada setiap pertemuan. Perangkat pembelajaran IPA berbasis model PBI terintegrasi pendidikan karakter dari hasil belajar siswa pada aspek keterampilan siswa dalam proses pembelajaran dengan presentase $95 \%$ berkategori sangat baik.

\section{DAFTAR PUSTAKA}

Akker, J. V. (1999). Principles and Methods of Development Research. In J. vam den Akker,R Branch,K Gustofson, N Nieveen and Tj.Plomp (Eds). Design Approaches and Tools in Education and Training (hlm.1-14). Dodrecht: Kluwer Academic Publisher.

Estuhono, Festiyed \& Alwen Bentri. (2020). Developing Of Physics Learning Devices Through Research Based Learning Model To Improve High Students' Four Cs in The 4.0 Industrial Revolution Era. International Journal Of Scientific \& Technology Research . 9 (1). 1-7. https://iopscience.iop.org/article/10.1088/17426596/1185/1/012041/pdf

Estuhono. (2017). Pengaruh Penerapan Strategi Pembelajaran Gasing (Gampang Asyik Menyenangkan) Berbantukan Animasi Terhadap Pencapaian Kompetensi Mahasiswa Pada Mata Kuliah Pendidikan IPA. Jurnal Bimbingan dan Konseling. 4 (1) : 8-13. http://jurnal.um-tapsel.ac.id/index.php/Ristekdik/article/view/214/193

Kurniawan. (2013). Integrasi Pendidikan Karakter ke dalam Pembelajaran Kewarganegaraan di Sekolah Dasar. Jurnal Pemikiran dan Pengembangan SD Jilid 1, Nomor (1):37-45.

Plomp, T. 2013. Educational design research. Netherlands: Netherlands Institute for Curiculum Development.

Rawa, N dkk. (2016). Pengembangan Perangkat Pembelajaran Berbasis Model Learning Cycle-7E pada Materi Trigonometri untuk Meningkatkan Kemampuan Koneksi Matematis Siswa. Jurnal Pendidikan 1 (6).

Riduwan. (2015). Belajar Mudah Penelitian untuk Guru-Karyawan dan Peneliti Pemula. Bandung: Alfabeta. 